\title{
Socioeconomic Functions of Private Green Spaces in a Residential Zone of Galle City, Sri Lanka
}

\author{
Jayasinghe, D. B. C..$^{*}$, Hemakumara, G.P.T.S., Hewage, P. \\ ${ }^{1}$ Faculty of Graduate Studies, University of Ruhuna \\ ${ }^{2,3}$ Department of Geography, University of Ruhuna
}

\begin{abstract}
Considering the current trends veered towards urbanization, it is forecast that by the end of the twentieth century, about $90 \%$ of the world's population would have resorted to urbanized living. Owing to the growing trend in urbanization, vast changes are taking place in relation to the distribution of the human settlements, which cast a rapid deterioration of green coverage in the metropolitan areas. Green spaces perform a variety of functions and important to the urban environment in many ways. 'Green space' is a crucial player, when it comes to the contribution it makes by improving the quality of the city environment. Its' contribution varies from improving of the quality of air, urban health, reducing urban heat island effect, lessening noise, conservation of biodiversity to bestowing significant socioeconomic advantages. Previous studies confirmed the important, beneficial role that the urban green spaces play in relation to the environment, society and economy. This paper evaluates the socio-economic functions of private green spaces in a primary residential zone of Galle City in Sri Lanka. Twelve variables were recognized for the purpose and the variables proposed were both qualitative and quantitative in nature. A survey with 280 residential units in the selected residential zone was carried out and the data was used in a multiple regression analysis. Models were developed to demonstrate the functions of private green spaces. Results revealed that only 13 percent of the private green spaces served for social functions. It was interesting to note that only a mere 5 percent of the private gardens served for economic functions. The role that the private gardens play in social functions was considerably higher than economic functions. Utilizing private garden spaces for recreational activities was substantially higher compared to the other social functions that they were used for. The findings emphasize that the private green spaces possess the ability to offer a variety of functions towards the positive contribution to the urban environment and its population, however it can be surmised that green spaces are not functioning in its' full potential in the city of Galle in Sri Lanka.
\end{abstract}

Keywords: Functions of green spaces, Private green space, Residential garden, Urban green spaces, Urbanization

\section{Introduction}

As projected by the UN, the world's urban population is expected to be increased by 2.5 billion by 2050 , and the rate of urbanization is expected to be at a faster in Asia and Africa than the other parts of the world. Accordingly, by 2050 , the urban populations in Asia and Africa will increase by $64 \%$ and $56 \%$ respectively. This is an indication that the urbanization will continue in a persistent journey (United Nations, 2014).

A feature common to urbanization in developing countries, is the intensity in which the crowds tend to populate around the main cities. When there is a

1*Corresponding Author

Dhttps://orcid.org/0000-0003-2844-6189

e-mail: tgup@sjp.ac.llk

DOI: http://doi.org/10.4038/bhumi.v8i1.77 
greater demand for residential properties within the urbanized areas the populations then choose to live in the peripheries. This suburbanization and the uncontrolled developments in the peripheries had a negative impact on the urban green space (Kong \& Nakagoshi, 2005), and clearly this warrants urgent attention. The ratios of both urban green and the pace at which the urban population grows, are not in a compatible state (Pauleit et al., 2005) and this has imposed a considerable weight on the urban environment to slowly decrease the quality of life of its inhabitants (Grimm et al., 2008; Johnson, 2001).

The term 'green spaces', refer to green areas of both public and private properties. Though each differ in their respective nature, the positive benefits meted out are of common stature. Gardens which are on private lands denotes a considerable proportion of the green spaces in areas which has a lower concentration of populace. By supporting a variety of functions and serving many purposes, residential green spaces play a very important role for the well-being of the metropolitan environment and its' population.

Pollution control, nature conservation, ecological benefits and biodiversity are a few of the environmental benefits provided by residential green spaces. Saving of energy and the enhancement of values in property are some of the economic and aesthetic benefits provided by these green spaces. The other advantages are of a social and a psychological kind, as it provides recreational space for meeting and interacting with the others (Shah \& Haq, 2011). Similarly, these advantages can be classified according to their social, environmental, and economic properties (Barber, 2005; Handley et al.,
2007; Swanwick et al., 2003; Dunnett et al., 2002).

A considerable number of studies, carried out specially in the Western countries, have examined the ways in which green spaces operate and are utilized. Though private gardens may be the commonest form of green space available in cities, only a few studies have been carried out with the view of evaluating its' numerous functions. Nonetheless, technical evidence with regard to green spaces in Sri Lanka, is extremely difficult to find as studies have not been conducted on practices on residential gardens in metropolitan areas. However, there is recorded evidence that shows how, for the past two decades, private gardens in the much-populated wet zone of Sri Lanka have been detrimentally impacted due to the sub-division of land and suburbanization (Pushpakumara et al., 2010). The study conducted by Manawadu et al. (2009), showed that suburban centres had undergone drastic changes since 1977, consequent to the induction of liberalized economic policies, which transformed not only the lifestyles, attitudes and economic trends but also the environments in metropolitan areas.

Sri Lanka has been placed as the 6th most vulnerable country in the word to climatic change impacts (Germanwatch, 2020). Suburbanization together with Climatic change will have a resounding effect on urban life and will definitely pose challenges to the whole of Sri Lanka. Studies have shown that the major cause of the unfavourable environmental impacts is the accelerated, mass scale development projects which transformed open green spaces into built up areas (Vailshery et al.,2013). The researchers have reported that the after-effects of this transformation would pave way for 
heightened vulnerability to heat strokes and ill-health conditions, creating serious health concerns for the people living in urban areas (Vailshery et al., 2013).

The researchers also declared that several South Asian countries were experiencing severe issues as a result of the atmospheric pollution with excessively high levels of Suspended Particulate Matter (SPM), $\mathrm{NO}_{2}, \mathrm{SO}_{2}$, and other air pollutants from higher pollution sources (e.g. vehicular traffic) and fewer heat sinks (e.g. reduced green cover). The above factors can cause adverse respiratory and health related issues among suburban dwellers, especially on the children and elderly. Hence, currently, the attention has been drawn in exploring the significant role that is played by green spaces, in the suburban areas.

The objective of this paper is to examine the diverse role that private green spaces play, in a primary residential zone in the city of Galle in Sri Lanka. Hence, it evaluates the functions of private green space in relation to social and economic aspects of this urban area.

\section{Research objectives}

The research has focused on three objectives:

a) To identify indicators to measure the Social and Economic functions of private green spaces;

b) To develop models to illustrate the Social and Economic functions of private green spaces;

c) To measure the functional ability of private green spaces in an urban city.

\section{Literature review}

\section{(a) Urban Green space}

Although the definition of 'green space' has been in dispute for a considerable time, a universally accepted definition has yet to be reached (Byomkesh et al., 2012). The European Commission (2013) defined 'green space' as a strategically planned network of high quality natural and partly built-up areas replete with many environmental features, designed and managed to deliver a wide range of ecosystem services and protect biodiversity, in both rural and urban settings. Jim \& Chen (2003) defined urban green spaces as vegetated areas found in urban environments that could be described as semi-natural areas, such as parks, forest patches, open spaces, residential gardens and long rows of trees lining one or both sides of a roadway.

\section{(b) Urban private gardens}

Cameron et al. (2012) defined private garden as the area adjoining a private dwelling, whether it is owned or rented, meaning that it was devoid of access to the general public. One of the key features of a private garden is that the owner enjoys absolute ownership and autonomy of his/her garden though the owner may have entrusted the design and maintenance duties such as landscaping, professional gardening, and caretaking of the areas, to respective people. Private gardens differ in shape, function, and size.

Private gardens play a significant role as they provide the urban dwellers with the ability to easily reach green space (Shanahan et al., 2014; Gaston et al., 2005). Nonetheless, they fulfil the important function of providing an overall green cover, since domestic areas provide more than $50 \%$ of the prevalent green areas in many of the 
metropolitan cities (Lin et al., 2015; Shanahan et al., 2014; Loram et al., 2007; Mathieu et al., 2007; Gaston et al., 2005).

\section{(c) Functions of Green spaces}

Suburban green areas perform numerous functions in the suburban context which accentuates the urban dweller's quality of life. Most of the research conducted on urban green areas, concentrated primarily on one key beneficial aspect or related specific benefits, including the following:

a) Environmental benefits such as providing temperate weather by controlling the warmth and cooling the area by providing shade and moisture, reduction in noise and filtration of airborne pollutants by passage through foliation and promoting of biodiversity.

b) Social benefits such as enabling social interaction and integration and also providing advantageous physical and mental aspects;

c) Economic benefits such as improved real estate prices due to the adjacent green spaces (Kabisch et al., 2015)

\section{(d) Social functions}

One of the main social functions supported by green spaces is related to health and well-being, enhanced by the relaxing mentality and refreshing nature afforded by the green areas. The positive impact afforded by the green spaces is an essential element when it comes to daily satisfaction, productivity of work and general health (Sorensen et al., 1997). A study conducted recently in Sweden, revealed that people who spent time outdoors enjoying the greenery showed a lesser amount of stress (Grahn \& Stigsdotter, 2003). Furthermore, a study in psychology found that in-house patients whose rooms faced green areas recuperated $10 \%$ faster and required $50 \%$ less intense pain lessening medicine compared to patients whose rooms faced the wall of a building (Heidt \& Neef, 2008).

Suburban green areas may also provide a place for the people to meet and interact, and thereby improving their social relations, taking part in many social activities (Kamierczak, 2013) Maintaining social relations is important to improve personal and social communication skills of the people. The existence of green areas and the establishment of neighborhood connections in suburban areas are of extreme importance in enhancing the sense of safety and adaption (Kuo et al., 1998).

A research carried out by Maas et al. (2006) revealed that the percentage of a green space in a person's residential area was positively associated with their perceived general health, and it was seen that this relationship was at its' strongest within the lower socioeconomic groups. Studies show that the green spaces cast a far more positive impact on the emotional recuperative effects to that of the way in which it impacts the physical health of a person (Croucher et al., 2007). Furthermore, the other research also revealed that the varying benefits that green areas have on the mental wellbeing as well as on the intellectual functions through physical access and usage of these environments (Whitelaw et al., 2008). This is further invigorated by the soothing and calming views of the sceneries (Ulrich, 1984).

\section{(e) Economic functions}

The advantages of urban green spaces can be analysed on economic terms such as averting the expense of constructing rainwater retention equipment; the lesser consumption of energy, reduced costs on health care 
consequent to the decrease in airpollution and the increase of outdoor activity.

One of the prime examples of a direct economic advantage is that of the increase in the property value of houses having a view over green areas, which is a commonly observed in many countries (Anthon et al., 2005; Kong et al., 2006). In Finland, houses which had a forest view recorded prices, 4\% higher than the others (Tyrvainen \& Miettinen, 2000) and in the Netherlands houses with a view of a park recorded a price hike of $8 \%$ (Luttik, 2000).

Bibliographic evidence presents that domestic gardens can contribute to income generation, improve livelihoods, support household economic welfare as well as promote entrepreneurship and rural development (Calvet-Mir et al., 2012; Trinh et al., 2003). After reviewing a several number of case studies, researchers Mitchell and Hanstad (2004) have observed a number of ways in which home gardens could maximize their economic potential and impact the income generation of the respective family : products from the garden could be easily sold, paving way for an additional income (Eyzaguirre et al., 2010; Torquebiau, 1992), gardening activities could be developed into small cottage industries, and income from the sale of home garden products and the savings made by consuming homegrown food products would lead to a higher disposable income that may be used for other domestic purposes.
Studies conducted in Nepal, Cambodia, and Papua New Guinea recorded that the income generated from the sale of home garden produce like fruits, vegetables and other livestock products enabled the households to establish their savings (Iannotti et al., 2009). Families in the mountainous areas of Vietnam were able to generate more than $22 \%$ of their cash income from home-gardening activities (Trinh et al., 2003).

(f) Measuring the functions of green spaces

The functions of the suburban green areas can vary from one location to another and are also complex in nature. Specific variables and indicators are necessary to gauge the value of the functions and the services rendered by these green areas. Indicators enable to reduce the complicatedness of data and simplify the interpretation and assessment and has facilitated the communication between experts and non-experts (Segnestam, 2002). Tables 1 and 2 exhibit a framework developed by Pakzada \& Osmonda (2015) for the formulation of an inclusive model in order to evaluate the functional level of green areas.

As seen through the above tables it is evident that green areas serve a variety of functions, and they are of a complicated and a multidimensional nature. Based on the ability of assessment, the following variables (Table 3) were chosen for this purpose of study. 
Table 1: Social Functions of Green Space

\begin{tabular}{|c|c|c|}
\hline Social functions & Indicators & References \\
\hline $\begin{array}{l}\text { Improving physical well- } \\
\text { being }\end{array}$ & $\begin{array}{l}\text { Physical outdoor activity; } \\
\text { healthy food; } \\
\text { healthy environment }\end{array}$ & $\begin{array}{l}\text { (Schipperijn et al., 2013; Li et al., } \\
\text { 2011; Kent, Thompson et al., 2011; } \\
\text { Abraham et al., 2010; Wilbur et al., } \\
\text { 2002; Ulrich, 1984) }\end{array}$ \\
\hline $\begin{array}{l}\text { Improving social well- } \\
\text { being }\end{array}$ & $\begin{array}{l}\text { Social interaction; } \\
\text { social integration; } \\
\text { community cohesion }\end{array}$ & $\begin{array}{l}\text { (Peschardt et al., 2012; Wood et al., } \\
\text { 2010; Maller et al., 2006; Frumkin } \\
\text { et al., 2004) }\end{array}$ \\
\hline $\begin{array}{l}\text { Improving mental well- } \\
\text { being }\end{array}$ & $\begin{array}{l}\text { Reduced depression and } \\
\text { anxiety; } \\
\text { recovery from stress; } \\
\text { attention restoration; } \\
\text { positive emotions }\end{array}$ & $\begin{array}{l}\text { Reduction of mental fatigue } \\
\text { (Arnberger \& Eder, 2012; Kuo \& } \\
\text { Sullivan, 2001; Kaplan \& Kaplan, } \\
\text { 1989) } \\
\text { Emotional and spiritual benefits } \\
\text { (Abraham et al., 2010; Milligan \& } \\
\text { Bingley, 2007; Chiesura, 2004) }\end{array}$ \\
\hline $\begin{array}{l}\text { Opportunities for } \\
\text { recreation, tourism and } \\
\text { social interaction }\end{array}$ & Community livability & $\begin{array}{l}\text { (Gobster \& Westphal, 2004; Nowak } \\
\text { et al., 2001) }\end{array}$ \\
\hline Food production & $\begin{array}{l}\text { Urban agriculture; } \\
\text { kitchen gardens; } \\
\text { edible crop landscape } \\
\text { and } \\
\text { community garden }\end{array}$ & (Clark \& Nicholas, 2013) \\
\hline $\begin{array}{l}\text { Provision of outdoor sites } \\
\text { for education } \\
\text { and research } \\
\end{array}$ & $\begin{array}{l}\text { Provision of outdoor sites } \\
\text { for education } \\
\text { and research }\end{array}$ & (McDonnell et al., 1997) \\
\hline $\begin{array}{l}\text { Reduction of crimes and } \\
\text { fear of crime }\end{array}$ & $\begin{array}{l}\text { Comfort; amenity and } \\
\text { safety }\end{array}$ & (Kuo \& Sullivan, 2001) \\
\hline $\begin{array}{l}\text { Attachment to a place and } \\
\text { sense of } \\
\text { belonging }\end{array}$ & $\begin{array}{l}\text { Cultural and symbolic } \\
\text { value }\end{array}$ & $\begin{array}{l}\text { (Kent, Thompson et al., 2011; Cohen } \\
\text { et al., 2008) }\end{array}$ \\
\hline
\end{tabular}

Table 2: Economic Functions of Green Space

\begin{tabular}{|l|l|l|}
\hline \multicolumn{1}{|c|}{ Economic functions } & \multicolumn{1}{|c|}{ Indicators } & \multicolumn{1}{|c|}{ References } \\
\hline Increased property values & Increased property values & $\begin{array}{l}\text { (Donovan \& Butry, 2010; Shoup } \\
\text { \& Ewing, 2010) }\end{array}$ \\
\hline Healthcare cost savings & Healthcare cost savings & $\begin{array}{l}\text { (Shoup \& Ewing, 2010; Bauman } \\
\text { et al., 2008) }\end{array}$ \\
\hline $\begin{array}{l}\text { Economic benefits of } \\
\text { provision services }\end{array}$ & $\begin{array}{l}\text { Raw materials; timber; food } \\
\text { products; biofuels; medicinal } \\
\text { products; fresh water, } \text { etc. }\end{array}$ & (Baines, 2000) \\
\hline $\begin{array}{l}\text { Value of avoided CO2 } \\
\text { emissions and carbon } \\
\text { sequestration }\end{array}$ & $\begin{array}{l}\text { Value of avoided CO2 } \\
\text { emissions and carbon } \\
\text { sequestration }\end{array}$ & (CNT 2010; Scott et al., 1998) \\
\hline $\begin{array}{l}\text { Value of avoided energy } \\
\text { consumption }\end{array}$ & $\begin{array}{l}\text { Reduced demands for } \\
\text { cooling and heating }\end{array}$ & $\begin{array}{l}\text { (CNT 2010; Akbari \& Taha, } \\
\text { 1992) }\end{array}$ \\
\hline $\begin{array}{l}\text { Greater local economic } \\
\text { activity }\end{array}$ & $\begin{array}{l}\text { Tourism, recreation, cultural } \\
\text { activities } \text { or other income } \\
\text { generating activity }\end{array}$ & $\begin{array}{l}\text { (Wolf, 2004; McPherson \& } \\
\text { Simpson, 2002) }\end{array}$ \\
\hline
\end{tabular}



Table 3: Selected variables to analyze the environment, social and economic function of private green space

\begin{tabular}{|c|c|c|}
\hline $\begin{array}{l}\text { Functional } \\
\text { category }\end{array}$ & Variables & Unit of analysis \\
\hline \multirow[t]{7}{*}{$\begin{array}{l}\text { Social } \\
\text { function }\end{array}$} & $\begin{array}{l}\text { Frequency of using of garden } \\
\text { for relaxation }\end{array}$ & \multirow{6}{*}{$\begin{array}{l}\text { Asked the participants to respond; } \\
\text { whether they use or do not use the } \\
\text { garden for these social activities }\end{array}$} \\
\hline & $\begin{array}{l}\text { Frequency of using of garden } \\
\text { to enjoy with family }\end{array}$ & \\
\hline & $\begin{array}{l}\text { Frequency of using of garden to meet } \\
\text { friends }\end{array}$ & \\
\hline & $\begin{array}{l}\text { Frequency of using of garden for social } \\
\text { gatherings }\end{array}$ & \\
\hline & $\begin{array}{l}\text { Frequency of using of garden for } \\
\text { education/studies }\end{array}$ & \\
\hline & $\begin{array}{l}\text { Frequency of using of garden for } \\
\text { play/for sport }\end{array}$ & \\
\hline & $\begin{array}{l}\text { Foods, provisions from garden } \\
\text { (Vegetables/fruits) }\end{array}$ & $\begin{array}{l}\text { Number of different types of } \\
\text { vegetables/fruits available in the } \\
\text { garden }\end{array}$ \\
\hline \multirow[t]{5}{*}{$\begin{array}{l}\text { Economic } \\
\text { functions }\end{array}$} & $\begin{array}{l}\text { Income received from the sale of garden } \\
\text { products }\end{array}$ & Rupees per month \\
\hline & Vegetables/fruits received from garden & \multirow{4}{*}{$\begin{array}{l}\text { Asked the participants to respond; } \\
\text { whether they received or do not } \\
\text { received these economic benefits }\end{array}$} \\
\hline & Timber received from garden & \\
\hline & Raw materials received from garden & \\
\hline & Medicinal plants received from garden & \\
\hline
\end{tabular}

The conceptual framework of the study is presented in Figure 1. The area of the private green space that is maintained by the respondents was measured as follows.

Where,
AEGA = Available space of gardening USG = Usable space for gardening

$$
\mathrm{PGA}=\frac{\mathrm{AEGA}}{\mathrm{USG}} \times 100
$$

PGA $=$ Private Green area

Figure 1: Relationship between dependent variable and independent variables

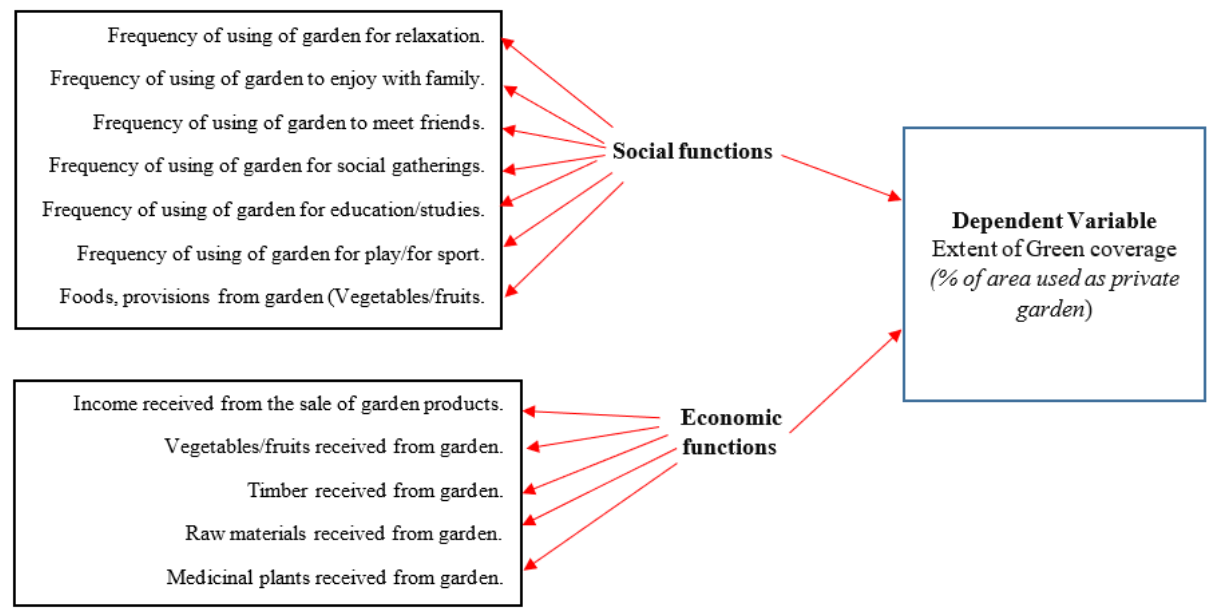




\section{The area and the sample}

\subsection{Study area}

Figure 2: Location map of Galle Municipal Council

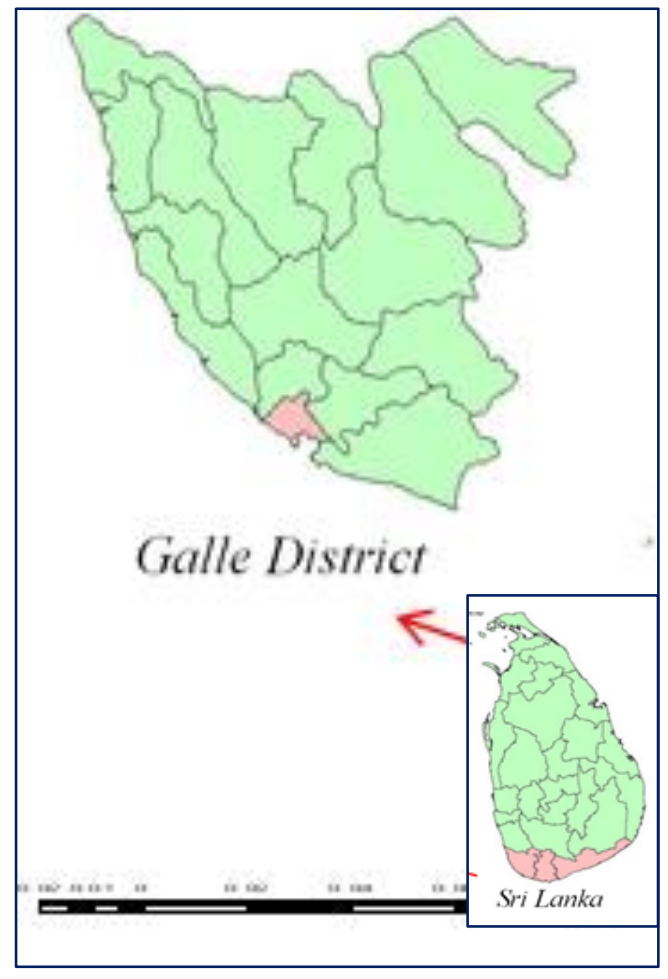

The City of Galle is located in the Wet Zone of Sri Lanka. It is considered to be the largest town in the Southern Province and operates as the District and Provincial capital. The Galle Municipal Council area covers an extent of 17.42 square kilometers and consists of 15 wards.

This urban area of the Galle Municipal Council was established in 1867 and declared as an 'Urban Development Area' under provisions of the Urban Development Authority law (Act No 41 of 1978) in 01.06.1979.

Its main objective was to deal more efficiently with the urban diversity that resulted with the rise in population within the area of the town. The latest Development Plan for the area includes a Zoning Plan to meet the development necessities of the area planned until 2025. According to the plan, the town is divided into 11 zones as presented in Figure 3.

Figure 3: Zoning plan of Galle MC

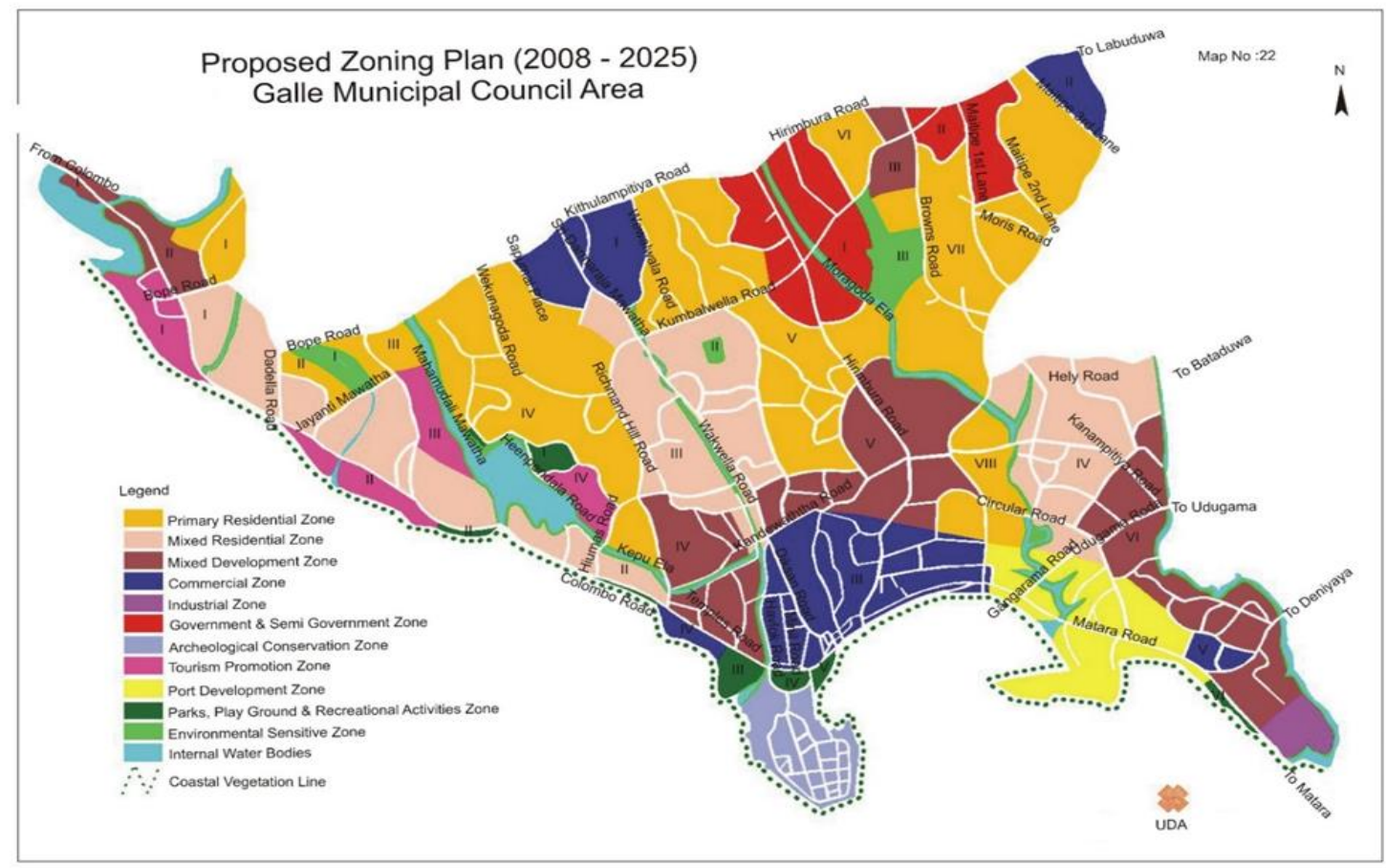


Figure 4: Primary residential zone selected for the survey

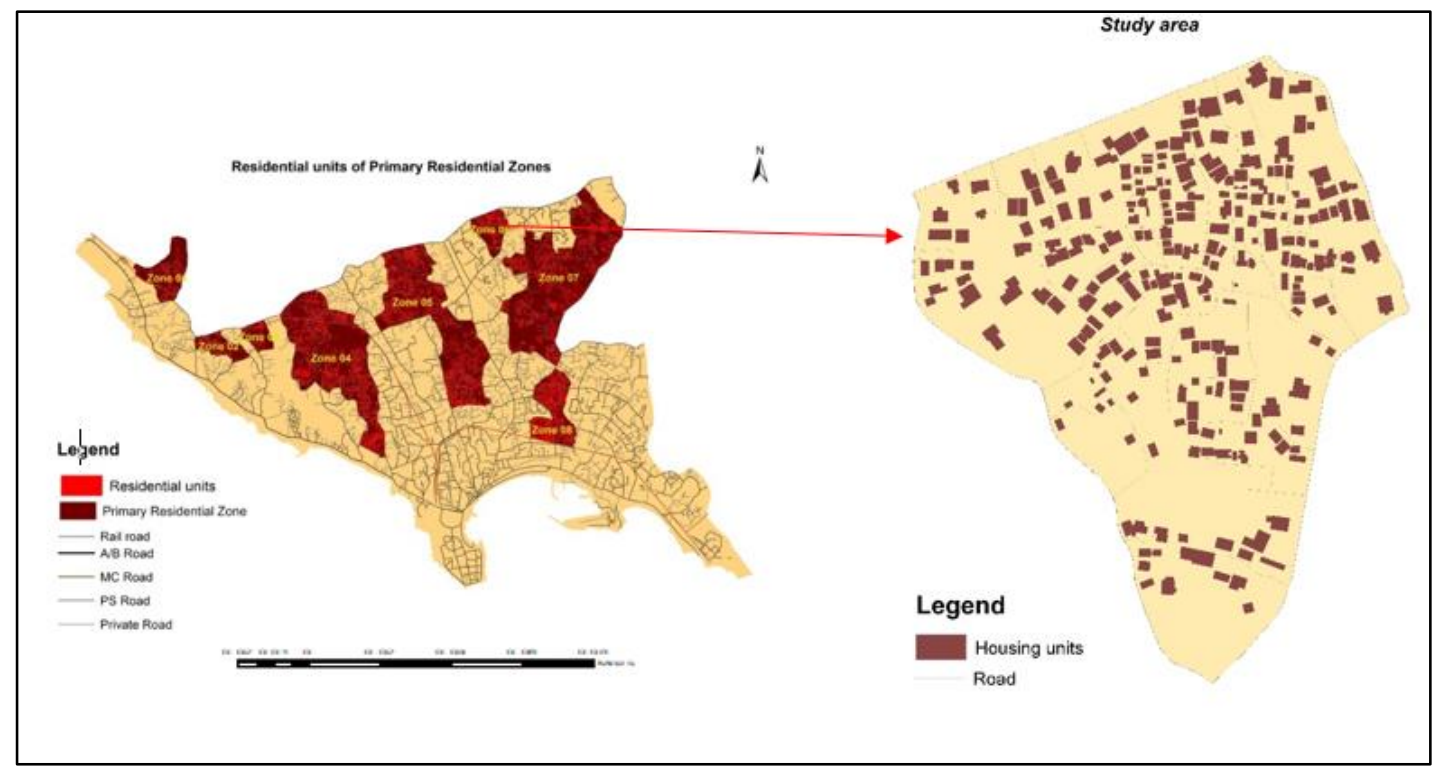

According to the said zoning plan (2008-2025), eight primary residential zones have been identified. In a subsequent analysis on the suitability levels, Jayasinghe et al. (2018) identified 'Primary residential zone 6' as the finest residential zone within Galle MC area (Figure 4). This has used GIS based weighted overlay analysis with the level of infrastructure, land value, road accessibility, and proximity to town center.

Hence, this zone was selected as the case study for this research. It includes 280 housing units and signifies $4 \%$ of the housing units of all the residential zones.

The sample carried 280 housing units and a population of 14,322 . Out of the total number of house owners, 112 were Buddhists, 162 were Muslims and 6 were Christians. This sample consisted of $189(68 \%)$ single story houses, 63 (23\%) two-story houses, and 14 (05\%) houses which are more than 2 stories. It also included 2 annex type houses and 6 temporary houses. 264 (95\%) of the houses were occupied by the owners while 16 were inhabited by rent-paying tenants.

$76(27 \%)$ houses were situated on land plots which were less than 6 perches (150 square meters) in extent and 83 $(30 \%)$ of the houses were situated on plots of 6-10 perches (150-250 square meters); while 68 (24\%) houses were on 10-15 perch (250-375 square meters) plots, 27 (09\%) were on 15-20 perch plots. A further 26 houses were situated on land plots which were more than 20 perches.

\subsection{The methodology}

A questionnaire survey was carried out on the 280 housing units for the collection of data, and the chief occupants of the households were the main respondents. The questionnaire had 10 questions under three sections: a) basic information regarding the green coverage, b) social function, and c) economic function of the respective private home garden. Multiple regression model was used for the analysis of the data. This model was preferred for three reasons. The first is that multiple regression indicates 
significant relationships, if there are any, between dependent variables. Second, it indicates the relative strengths of the effects of different independent variables on a dependent variable, and third, it provides the researcher with a predictive capacity indicating trend patterns (Eric, 2014).

The dependent variable was identified to be the percentage of land area which is already being utilized as a private garden area, out of the total land extent available for the garden. The analysis was carried out with seven independent variables. The data that was collected was analyzed using IBM SPSS Statistics 25. Consequently, three separate models were formulated to explain the functions of the private gardens.

\section{Analysis}

\subsection{Regression Analysis}

Regression analysis is a powerful statistical method that allows one to examine the relationship between two or more variables of interest. In this research, the dependent variable is the coverage of green area supported by the residents and as for the independent variables, the respective study carries altogether 7 variables.

Model A - Social function of private green space

This model was created based on the selected seven variables as shown in Table 4.

Table 4: Coefficient Table of Model A

\section{Coefficients $^{\mathrm{a}}$}

\begin{tabular}{|c|c|c|c|c|c|c|c|}
\hline \multirow[t]{2}{*}{ Model } & \multicolumn{2}{|c|}{$\begin{array}{l}\text { Unstandardized } \\
\text { Coefficients }\end{array}$} & \multirow{2}{*}{$\begin{array}{c}\begin{array}{c}\text { Standardized } \\
\text { Coefficients }\end{array} \\
\text { Beta }\end{array}$} & \multirow[t]{2}{*}{$\mathbf{t}$} & \multirow[t]{2}{*}{ Sig. } & \multicolumn{2}{|c|}{$\begin{array}{l}\text { Collinearity } \\
\text { Statistics }\end{array}$} \\
\hline & B & $\begin{array}{l}\text { Std. } \\
\text { Error }\end{array}$ & & & & $\begin{array}{l}\text { Toler } \\
\text { ance }\end{array}$ & VIF \\
\hline (Constant) & 9.334 & 0.820 & & 11.380 & .000 & & \\
\hline $\begin{array}{l}\text { No. of types of Fruits \& } \\
\text { Vegetables (NOTFV) }\end{array}$ & 1.562 & 0.143 & 0.451 & 10.903 & .000 & 0.415 & 2.411 \\
\hline $\begin{array}{l}\text { Using the garden for } \\
\text { relaxation/ thinking (D1) }\end{array}$ & 8.677 & 2.129 & 0.152 & 4.075 & .000 & 0.514 & 1.944 \\
\hline $\begin{array}{l}\text { Using garden to enjoy with } \\
\text { family (D2) }\end{array}$ & 100 & 1.998 & 0.053 & 1.492 & & 0.574 & 1.743 \\
\hline $\begin{array}{l}\text { Using garden to meet } \\
\text { friends (D3) }\end{array}$ & 10.840 & 1.784 & 0.213 & 6.076 & .000 & 0.576 & 1.736 \\
\hline $\begin{array}{l}\text { Using garden for social } \\
\text { gathering (D4) }\end{array}$ & 10.704 & 2.370 & 0.149 & 4.517 & .000 & 0.653 & 1.532 \\
\hline $\begin{array}{l}\text { Using garden for } \\
\text { education/ studies (D5) }\end{array}$ & 4.286 & 2.019 & 0.073 & 2.123 & .035 & 0.606 & 1.650 \\
\hline $\begin{array}{l}\text { Using garden for play/ } \\
\text { sports (D6) }\end{array}$ & 2726 & 1.754 & 0.055 & 1.560 & 10 & 0.569 & 1.757 \\
\hline
\end{tabular}

a. Dependent Variable: Extent of the green area 
As shown in Table $8, \mathrm{P}$ values of all variables except D2 and D6 are less than 0.05 and $t$ values of all variables except D2 and D6 are greater than 1.96. Therefore, the model to illustrate the social function is developed as follows: Social function of private green area $($ SPGA $)=9.334+1.562($ NOTFV $)+$ 8.677 (D1) + 10.840 (D3) +10.704 (D4) +4.286 (D5)

NOTFV $=$ No. of types of fruits and vegetables

D1 (Dummy 1); $1=$ Using the garden for relaxation/thinking $0=$ Otherwise

D2 (Dummy 3); 1 = Using the garden to meet friends $0=$ Otherwise

D3 (Dummy 4); 1 = Using the garden for social functions $0=$ Otherwise

D4 (Dummy 5); $1=$ Using the garden for education and studies $0=$ Otherwise

The model value was substituted and the $\hat{Y}$ value was taken for every housing unit. These data were inserted in the Geographic Information System (GIS) platform, where 'one house' was considered as the unit of analysis to map out the social function of residential green space (Figure 5).

Figure 5: Social functions of private gardens

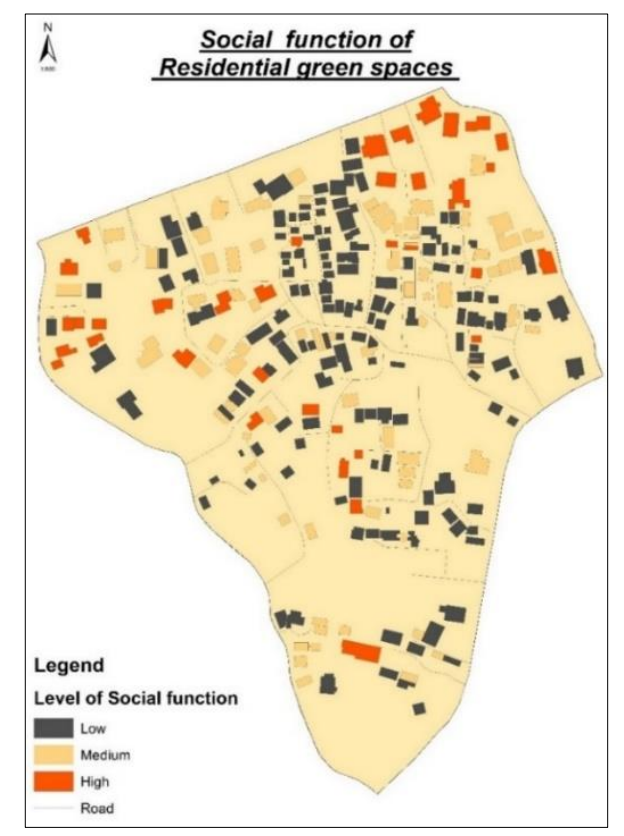

Table 5 presents the level of functioning ability as a percentage. The $\hat{Y}$ values below 20 is considered as none function, in between 20-50 considered as low function, between 50-75 considered as medium function and above 75 considered as high function. According to the analysis only $13 \%$ of the residential gardens are socially functioning well in the study area.

Table 5: Level of social functions of private gardens

\begin{tabular}{|l|l|}
\hline $\begin{array}{l}\text { Social Functional } \\
\text { Factor }\end{array}$ & Involvement \\
\hline $\begin{array}{l}\text { Using private garden } \\
\text { for relaxation }\end{array}$ & $16 \%$ \\
\hline $\begin{array}{l}\text { Using private garden } \\
\text { to enjoy with family }\end{array}$ & $16 \%$ \\
\hline $\begin{array}{l}\text { Using private garden } \\
\text { to meet friends }\end{array}$ & $21 \%$ \\
\hline $\begin{array}{l}\text { Using private garden } \\
\text { for social functions }\end{array}$ & $9 \%$ \\
\hline $\begin{array}{l}\text { Using private garden } \\
\text { for education/studies }\end{array}$ & $15 \%$ \\
\hline $\begin{array}{l}\text { Using private garden } \\
\text { to play/for sport }\end{array}$ & $23 \%$ \\
\hline
\end{tabular}

Table 6 shows the average value of social functional factors as a percentage. According to that, it could be seen that the commonest use for private gardens is for recreational purposes like play and sport.

Table 6: Percentage value of using private gardens for different social activities

\begin{tabular}{|l|l|l|}
\hline $\begin{array}{c}\text { Level of } \\
\text { social } \\
\text { function }\end{array}$ & $\begin{array}{c}\text { No. of } \\
\text { Housing } \\
\text { units }\end{array}$ & $\%$ \\
\hline None & 0 & 0 \\
\hline Low & 165 & 59 \\
\hline Medium & 79 & 28 \\
\hline High & 36 & 13 \\
\hline
\end{tabular}


Model B - Economic functions of private gardens

The following model was formulated based on the selected five factors under the economic functions of private green space as shown in Table 7.

Figure 7 shows the economic functions of private green spaces under the study area. The $\hat{Y}$ value is below 20 is considered as none function, in between 20-50 considered as low function, between 50-75 considered as medium function and above 75 considered as high function. According to Table 8, only $5 \%$ of the residential gardens are economically functioning well. According to Table 9, The main benefit they derived was the production of food from the private gardens, while the other factors displayed low contributions. Therefore, the model to illustrate the economic functions was developed as follows (Table 8-9):

Table 7: Coefficient table of Model B

\begin{tabular}{|c|c|c|c|c|c|c|c|}
\hline \multicolumn{8}{|c|}{ Coefficients } \\
\hline \multirow[t]{2}{*}{ Model } & \multicolumn{2}{|c|}{$\begin{array}{c}\text { Unstandardized } \\
\text { Coefficients }\end{array}$} & \multirow{2}{*}{$\begin{array}{c}\begin{array}{c}\text { Standardized } \\
\text { Coefficients }\end{array} \\
\text { Beta }\end{array}$} & \multirow[t]{2}{*}{$\mathbf{t}$} & \multirow[t]{2}{*}{ Sig. } & \multicolumn{2}{|c|}{$\begin{array}{l}\text { Collinearity } \\
\text { Statistics }\end{array}$} \\
\hline & B & $\begin{array}{l}\text { Std. } \\
\text { Error }\end{array}$ & & & & $\begin{array}{l}\text { Toler } \\
\text { ance }\end{array}$ & VIF \\
\hline 1 (Constant) & 13.91 & 1.221 & & 10.967 & .000 & & \\
\hline $\begin{array}{l}\text { Income received from } \\
\text { garden (IRFG) }\end{array}$ & 0.002 & 0.000 & 0.204 & 4.851 & .000 & 0.965 & 1.036 \\
\hline $\begin{array}{l}\text { Raw Materials received } \\
\text { from garden (D1) }\end{array}$ & 19.326 & 4.220 & 0.195 & 4.580 & .000 & 0.939 & 1.065 \\
\hline $\begin{array}{l}\text { Timber received from } \\
\text { garden (D2) }\end{array}$ & 38.103 & 5.079 & 0.323 & 7.501 & .000 & 0.922 & 1.084 \\
\hline $\begin{array}{l}\text { Food production services } \\
\text { from garden (D3) }\end{array}$ & 14.134 & 1.858 & 0.338 & 7.607 & .000 & 0.864 & 1.157 \\
\hline $\begin{array}{l}\text { Products of Medicinal } \\
\text { plants from garden (D4) }\end{array}$ & 10.163 & 2.249 & 0.203 & 4.519 & .000 & 0.851 & 1.176 \\
\hline
\end{tabular}

a. Dependent Variable: Extent of the green area

Table 8: Level of economic functions of private gardens

\begin{tabular}{|l|r|r|}
\hline Level of Economic function & No. of Housing units & $\%$ \\
\hline None & 0 & 0 \\
\hline Low & 220 & 78 \\
\hline Medium & 47 & 17 \\
\hline High & 13 & 5 \\
\hline
\end{tabular}


Table 9: Percentage value of using private gardens for different economic activities

\begin{tabular}{|l|l|}
\hline $\begin{array}{l}\text { Economic functional Factor } \\
\text { (using private garden for } \\
\text { economic service activities) }\end{array}$ & $\begin{array}{l}\text { Involve } \\
\text { ment }\end{array}$ \\
\hline Raw materials & $05 \%$ \\
\hline Timber & $03 \%$ \\
\hline Food production & $48 \%$ \\
\hline Medicinal plants & $22 \%$ \\
\hline
\end{tabular}

Ec.FPGA $=13.39+$ 0.002(IRFG) + 19.326(D1) + 38.103(D2) + 14.134(D3) + 10.163(D4)

Ec.FPGA = Economic functions of private green area

IRFG = Income received from private garden

D1 (Dummy 1); 1 = Raw materials received from private garden $0=$ Otherwise

D2 (Dummy 2); 1 = Timber received from private garden $0=$ Otherwise

D3 (Dummy 3); 1 = Food production service from private garden $0=$ Otherwise

D4 (Dummy 4); 1 = Products of medicinal plants from private garden $0=$ Otherwise

Figure 7: Economic functions of private garden

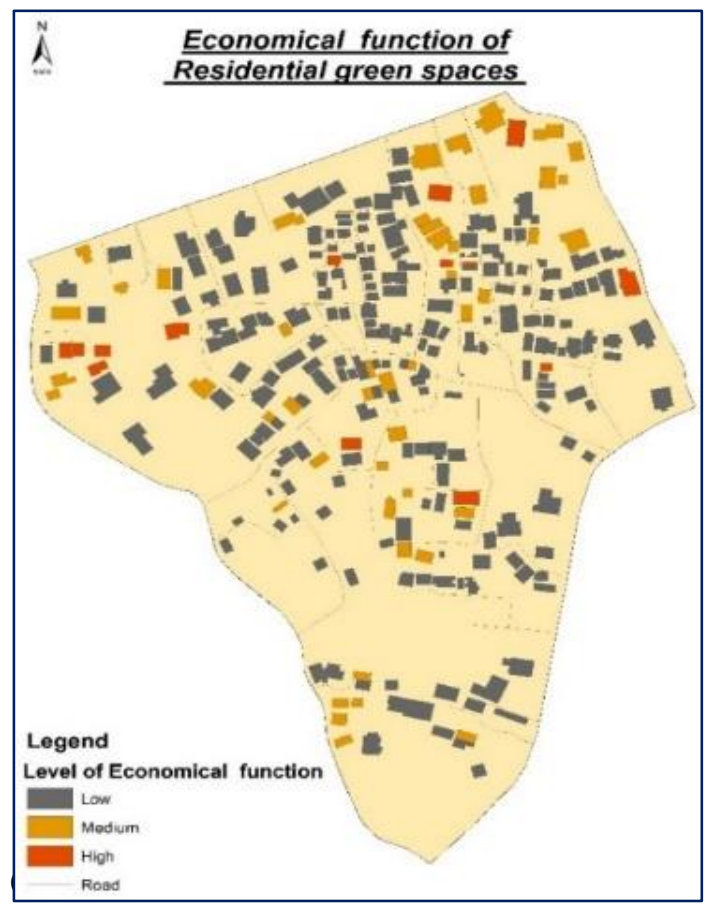

Residential green areas provide a variety of functions, which can contribute significantly, greatly aiding the suburban environment and its population. Usually, residents in lands of less than 6 perches were not able to maintain a sufficient area for greenery. It could be observed that the mean extent of the open green area maintained by the residences in plots less than 6 perches was less than one fifth (18.8\%) and 6-10 perch lands maintained one fifth $(21.4 \%)$. Furthermore, residents in $10-15$ perch lands maintained average $30 \%$, residents in 15-20 perch lands maintained it at $28 \%$ and those who owned more than 20 perches maintained average $38 \%$ of open green space.

The study found that private gardens performed a variety of functions, but the level of functioning differed according to the category. A residential garden can undoubtedly be the source for many socioeconomic benefits. For example, it can be easily used for recreational purposes, while the value of the land increased significantly.

According to this study, only $36 \%$ of the house-owners derived the social benefits from their respective gardens. Social functions of private green areas were assessed based on factors such as enhanced physical and social well-being.

Considering the private gardens which were subject to the current study, it was observed that utilizing the open garden spaces to interact with friends and associates and engage in recreational activities is substantially higher compared to the other social functions that it could be used for.

The economic function of these green spaces was measured considering two variables, namely, the economic advantages derived from the provision of services, and the income generation potential through the home garden. But results showed that only $5 \%$ were deriving economic advantage from respective home gardens. Generation of income from the trading of garden products such as fruits, vegetables, medicinal plants, timber, and ornamental plants was 
perceived as the economic benefit that could be reaped from these private gardens.

And according to the analysis of the current research, the average income generation through private green spaces is around Rs. 265.00 in the study area.

\section{Conclusion \& discussion}

With the world's cities continuing to grow, the value of the green areas in the suburbs of cities will keep increasing. However, it is imperative that areas are designated as green spaces in urban areas solely for the reasons that have been elaborated at length here. Nonetheless, this will pose a big challenge in the future, specifically in the developing countries where there is severe pressure for land, which is a pivotal aspect in all developmental activities. Hence, it is necessary to address this issue swiftly and find innovative solutions. The rationale of this paper is to assess the multifarious social economical functions of private green space in a residential zone of Galle City, Sri Lanka.

The present study entailed some limitations, yet it also provides possible paths for future research. First, the selected sample signifies the occupants living in an elitist zone of the Galle city, which carried only $4 \%$ of the housing units of all the residential zones. Repetition of this study in other residential areas with a larger, representative sample is required for a valid generalization.

Secondly, the results of this study have presented the probability of formulating a model that explains the functions of a green space in a suburban area. The respective model can be further enhanced by further studying the variables mentioned in literature review. This study reflected only on 12 variables, but there are more variables that explains the functions of private green spaces or home gardens in a suburban city. These variables can be used in further research on this matter.

Evidently, having usable spacious private home gardens are likely to diminish the use of public green spaces. The current planning guidelines and regulations need to be enhanced to encourage greenery in residential lands in urban areas. Based on the results of this study, the researcher recommends making aware of people on multifarious functions of private green spaces in home gardens to encourage greenery in all areas of Sri Lanka.

\section{References}

Abraham, A., K. Sommerhalder K. Abel T. (2010). Landscape and well-being: a scoping study on the healthpromoting impact of outdoor environments. International Journal of Public Health, 55(1): 56-59. https://doi.org/10.1007/s00038-009-0069-z.

Adams, L.W. (1994). In our own backyard: Conserving urban wildlife. Journal of Forestry 92, 24-25. https://doi.org/10.1093/jof/92.10.24

Akbari, H. (2002). Shade trees reduce building energy use and CO2 emissions from power plants. Environmental Pollution 116 (1), 119-126. https://doi.org/10.1016/S0269-7491(01)00264-0

Akbari, H.; Pomerantz, M.; Taha, H. (2001). Cool surfaces and shade trees to reduce energy use and improve air quality in urban areas. Solar Energy, 70 (3),295-310. https://doi.org/10.1016/S0038-092X(00)00089-X

Akbari, H.; Taha, H. (1992). The impact of trees and white surfaces on residential heating and cooling energy use in four Canadian cities. Energy, 17 (2),141-149.

Armson, D., Stringer, P., Ennos, A.R. (2012). The effect of tree shade and grass on surface and globe temperatures in an urban area. Urban Forestry \& Urban Greening, 11 (3),245-255. https://doi.org/10.1016/j.ufug.2012.05.002

Arnberger, A.; Eder, R. (2012). Exploring coping behaviours of Sunday and workday visitors due to dense use conditions in an urban forest. Urban Forestry \& Urban Greening 11 (4),439-449. https://doi.org/10.1016/j.ufug.2012.08.002 
Astbury, B. and P. Rogers (2004). Evaluation of the Stronger Families and Communities Strategy: Gilles Plains Community Garden: A case study, RMIT University Collaborative Institute for Research

Baines, C. (2000). A forest of other issues. Landscape Design, 294, 46-47.

Barber, A. (2005) Green future - a study of the management of multifunctional urban green spaces in England, Green Space Forum Ltd, England.

Boland, P., \& Sven, H. (1999). Ecological services in urban areas, Ecological Economics, 29, $293-301$. https://doi.org/10.1016/S0921-8009(99)00013-0

Byomkesh, T., Nakagoshi, N., Dewan, A.M. (2012): Urbanization and green space dynamics in Greater Dhaka, Bangladesh. - Landscape Ecological Engineering 8:45-58. https://doi.org/10.1007/s11355-010-0147-7.

Calvet-Mir L, Gómez-Bagetthun E, Reyes-García V. (2012) Beyond food production: Home gardens" ecosystem services. A case study in Vall Fosca. Ecol Econ, 74, 153-160. https://doi.org/10.1016/j.ecolecon.2011.12.011

Cameron, R. W. F., Blanuša, T., Taylor, J. E., Salisbury, A., Halstead, A. J., Henricot, B., \& Thompson, K. (2012). The domestic garden - Its contribution to urban green infrastructure. Urban Forestry \& Urban Greening, 11(2), 129-137. https://doi.org/10.1016/j. ufug.2012.01.00

Chiesura, A. (2004). The role of urban parks for the sustainable city. Landscape and Urban Planning, 68 (1), 129-138. https://doi.org/10.1016/j.landurbplan.2003.08.003

Clark, K.H. \& Nicholas, K.A. (2013). Introducing urban food forestry: A multifunctional approach to increase food security and provide ecosystem services. Landscape Ecology, 28 (9),1649-1669. https://doi.org/10.1007/s10980-013-9903-z

CNT (2010). Integrating valuation methods to recognize green infrastructure's multiple benefits, Center for Neighborhood Technology.

Cohen, D. A., Inagami, S., \& Finch, B. (2008). The built environment and collective efficacy. Health \& place, 14(2), 198-208. https://doi.org/10.1016/j.healthplace.2007.06.001

Croucher, K., Myers, L. \& Bretherton, J. (2007). The links between greenspace and health: a critical literature review. Greenspace Scotland, Stirling.

Donovan, G.H.; Butry, D.T. (2010). Trees in the city: Valuing Street trees in Portland, Oregon. Landscape and Urban Planning, 94 (2), 77-83. https://doi.org/10.1016/j.andurbplan.2009.07.019

Dunnett, N., Swanwick, C. \& Woolley, H. (2002) Improving urban parks, play areas and green spaces, The Department of Transport, London.

Duryea, M.L. Blakeslee, G.M.; Hubbard, W.G. \& Vasquez, R.A. (1996). Wind and trees: A survey of homeowners after hurricane Andrew. Journal of Arboriculture, 22 (1), 44-50. Available at https://auf.isaarbor.com/request.asp?JournalID $=1 \&$ ArticleID $=2708 \&$ Type $=2$ [Accessed on $20^{\text {th }}$ June 2021)

Eric M., (2014). Regression analysis. A Concise Guide to Market Research, https://doi.org/10.1007/978-3642-53965-7 7

European Commission (2013): Building a Green Infrastructure for Europe. Publications Office of the European Union. https://doi.org/10.2779/54125

Eyzaguirre P.B, Linares O.F. (eds) (2004) Introduction. Home gardens and Agrobiodiversity. 1-28, Washington DC, USA: Smithsonian Books. Available at https://hdl.handle.net/10568/104856 [last accessed 28 June 2021]

Frumkin, H., L. Frank, et al. (2004). Urban sprawl and public health. Washington, Island Press. https://doi.org/10.1093/phr/117.3.201

Gaston K.J, Warren P.H, Thompson K, \& Smith R.M. (2005). Urban Domestic Gardens (IV): The extent of the Resource and its Associated Features. Biodiversity and Conservation 14, 3327-3349. http://dx.doi.org/10.1007/s10531-004-9513-9 
Germanwatch (2020) Global climatic risk reduction index. Available at https://www.germanwatch.org/sites/default/files/20-2-

01e\%20Global\%20Climate\%20Risk\%20Index\%202020_14.pdf [last accessed 1 July 2021]

Gill, S.E., Handley, J.F., Ennos, A.R. \& Pauleit, S. (2007). Adapting cities for climate change: the role of green infrastructure. Built Environment, 33 (1), 115-133. https://doi.org/10.2148/benv.33.1.115

Gobster, P.H.; Westphal, L.M. (2004). The human dimensions of urban greenways: Planning for recreation and related experiences. Landscape and Urban Planning, 68 (2-3),147-165. https://doi.org/10.1016/S01692046(03)00162-2

Grahn, P., \& Stigsdotter, U. A. (2003). Landscape planning and stress, Urban Forest: Urban for Urban Green, 2, 1-18. https://doi.org/10.1078/1618-8667-00019

Grimm, N. B., Foster, D., Groffman, P., Grove, J. M., Hopkinson, C. S., Nadelhoffer, K. J., Pataki, D.E., Peters, D.P. (2008). The changing landscape: ecosystem responses to urbanization and pollution across climatic and societal gradients. Frontiers in the Ecology and the Environment. 6, 264-272. https://doi.org/10.1890/070147

Grimmond, S. (1994). Local scale energy and water exchange in a Chicago neighbourhood. Chicago's Urban Forest Ecosystem: Results of the Chicago Urban Forest Climate Project. Available at https://www.academia.edu/2807925/Local_scale_energy_and_water_exchanges_in_a_Chicago_neighborhoo d [last accessed 1 July 2021]

Heidt, V., \& Neef, M. (2008). Benefits of urban green space for improving urban climate. Ecology, Planning, and Management of Urban Forests, Springer, New York. https://doi.org/10.1007/978-0-387-71425-7_6

Heidt, V., \& Neef, M. (2008). Ecology, planning and man-argument of urban forests: International perspective, Springer, UK.

Iannotti, L., Cunningham, K., \& Ruel M. T., (2012) Improving Diet Quality and Micronutrient Nutrition: Homestead Food Production in Bangladesh. 2009, Discussion Paper 00928, Washington DC, USA: International Food Policy Research Institute

Islam, M.N., Rahman, K.S., Bahar, M.M., Habib, M.A., Ando, K., \& Hattori, N. (2012). Pollution attenuation by roadside greenbelt in and around urban areas. Urban Forestry \& Urban Greening, 11 (4),460-464. https://doi.org/10.1016/j.ufug.2012.06.004

Jayasinghe, B., (2018).Measuring the suitability of urban residential zone in Galle city : a GIS analysis, In the Proceedings of $6^{\text {th }}$ International Urban design Conference ICCPP-2018, University of Moratuwa, Sri Lanka

Jim, C.Y., Chen, S.S. (2003): Comprehensive greenspace planning based on landscape ecology principles in compact Nanjing city, China. Landscape Urban Planning, 65:95. https://doi.org/10.1016/S01692046(02)00244-X

Johnson, M. P., (2001). Environmental impacts of urban sprawl: a survey of the literature and proposed research agenda. Environment Planning, A33,717-735. https://doi.org/10.1068/a3327

Jouraeva, V.A., Johnson, D.L. Hassett, J.P. and Nowak, D.L. (2002). Differences in accumulation of PAHs and metals on leaves of Tilia x euchlora and Pyrus calleryana. Environmental Pollution, 120, 331-338.

Kabisch, N. S. \& Qureshi, E., \& Haase, D. (2015). Human-environment interactions in urban green spacesA systematic review of contemporary issues and prospects for future research, Environmental Impact Assessment Review, 50, 25-34. https://doi.org/10.1016/j.eiar.2014.08.007

Kamierczak, A. (2013): The contribution of local parks to neighbourhood socialites, - Landscape and Urban Planning, 109:31-44. http://dx.doi.org/10.1016/j.landurbplan.2012.05.00...

Kaplan, R.; Kaplan, S. (1989). The experience of nature: A psychological perspective. Cambridge University Press: Cambridge.

Kent, J., S. M. Thompson, et al. (2011). Healthy Built Environments: A review of the literature. City Futures Research Centre, Sydney.

Kong, F., Nakagoshi, N. (2005): Spatial-temporal gradient analysis of urban green spaces in Jinan, China. Landscape and Urban Planning, 78, 147-164. https://doi.org/10.1016/j.landurbplan 
Kong, F., Yin, H., Nakagoshi, N., \& Zong, Y. (2010). Urban green space network development for biodiversity conservation: Identification based on graph theory and gravity modeling. Landscape and Urban Planning, 95(1), 16-27. https://doi.org/10.1016/j. landurbplan.2009.11.001

Kuo FE, Sullivan WC, Coley RL et al. 1998, Fertile ground for community: inner-city neighbourhood common spaces, American Journal of Community Psychology, 26(6):823-51. https://doi.org/10.1023/A:1022294028903

Kuo, F.E.; Sullivan, W.C. (2001). Aggression and violence in the inner city: Effects of environment via mental fatigue. Environment and Behavior, 33 (4),543. https://doi.org/10.1177/00139160121973124

L. Lours, R. Santos \& P. Thomas, (2007), Urban Parks and Sustainable Development: The case study of Partimao city, Portugal, In the Proceedings of Conference on Energy, Environment, Ecosystem and Sustainable Development, Greece.

Li, Q. Otsuka, T. Kobayashi, M. Wakayama, Y.; Inagaki, H. Katsumata, M. Hirata, Y. Li, Y.; Hirata, K. \& Shimizu, T. (2011). Acute effects of walking in forest environments on cardiovascular and metabolic parameters. European Journal of Applied Physiology, 111 (11), 2845-2853. https://doi.org/10.1007/s00421$\underline{011-1918-\mathrm{Z}}$

Lin, B., Fuller, R. A., Bush, R., Gaston, K. J., \& Shanahan, D. F. (2015). Opportunity or orientation? Who uses urban parks and why. PLoS one, 9(1), e87422. https://doi.org/10.1371/journal.pone.0087422

Loram, A., Tratalos, J., Warren, P. H., \& Gaston, K. J. (2007). Urban domestic gardens (X): the extent \& structure of the resource in five major cities. Landscape Ecology, 22(4), 601-615. https://doi.org/10.1007/ s10980-006-9051-

Luttik, J., 2000. The value of trees, water and open spaces as reflected by house prices in the Netherlands. Landscape and Urban Planning, 48(3-4), pp. 161-167. https://doi.org/10.1016/S0169-2046(00)00039-6

Maas, J., Verheij, R. A., Groenewegen, P. P., de Vries, S. \& Spreeuwenberg, P. (2006). Green space, urbanity and health: how strong is the relation? Journal of Epidemiology and Community Health, 60 (7), 587-592. http://dx.doi.org/10.1136/jech.2005.043125

Maller, C., Townsend, M., Pryor, A., Brown, P., St Leger, L. (2006). Healthy nature healthy people: 'contact with nature' as an upstream health promotion intervention for populations. Health Promotion International, 21(1), 45-54. http://dx.doi.org/10.1093/heapro/dai032

Mathieu, R., Freeman, C., \& Aryal, J. (2007). Mapping private gardens in urban areas using object-oriented techniques and very high-resolution satellite imagery. Landscape and Urban Planning, 81(3), 179-192. https://doi.org/10.1016/j. landurbplan.2006.11.00

McDonnell, M.J. Pickett, S.T.A. Groffman, P. Bohlen, P. Pouyat, R.V. Zipperer, W.C. Parmelee, R.W. Carreiro, M.M. \& Medley, K. (1997). Ecosystem processes along an urban-to-rural gradient. Urban Ecosystems, 1 (1), 21-36. Available at https://link.springer.com/content/pdf/10.1023/A:1014359024275.pdf [last accessed 1 July 2021]

McKinney, M.L. (2006). Urbanization as a major cause of biotic homogenization. Biological Conservation, 127 (3), 247-260. https://doi.org/10.1016/j.biocon.2005.09.005

McPherson, E.G. \& Simpson, J.R. (2002). A comparison of municipal forest benefits and costs in Modesto and Santa Monica, California, USA. Urban Forestry \& Urban Greening, 1 (2),61-74. https://doi.org/10.1078/16188667-00007

Milligan, C. \& Bingley, A. (2007). Restorative places or scary spaces? The impact of woodland on the mental well-being of young adults. Health and Place 13, 799-811.

Mitchell, R, Hanstad, T. (2004). Small home garden plots and sustainable livelihoods for the poor, Rome, Italy.

Nettle, C. (2009). Growing community: Starting and nurturing community gardens. Government of South Australia and Community and Neighbourhood Houses and Centres, Adelaide.

Nowak, D. J. (1994). Air pollution removal by Chicago's urban forest, Chicago's Urban Forest Ecosystem. Chicago Urban Forest Climate Project, United States Department of Agriculture, United States. 
Nowak, D.J. \& Crane, D.E. (2002). Carbon storage and sequestration by urban trees in the USA. Environmental Pollution, 116 (3), 381-389. https://doi.org/10.1016/S0269-7491(01)00214-7

Pauleit, S., Ennos, R., \& Golding, Y. (2005). Modeling the environmental impacts of urban land use and land cover change - a study in Mersey side, UK. Landscape Urban Planning, 71, 295-310. https://doi.org/10.1016/j.landurbplan.2004.03.009

Peschardt, K. K. Schipperijn, J., \& Stigsdotter, U. K. (2012). Use of small public urban green spaces. Urban Forestry \& Urban Greening, 11 (3), 235-244. https://doi.org/10.1016/j.ufug.2012.04.002

Picot, X. (2004). Thermal comfort in urban spaces: Impact of vegetation growth case study: Piazza dellascienza, Milan, Italy. Energy \& Buildings, 36 (4), 329-334.

https://doi.org/10.1016/j.enbuild.2004.01.044

Pushpakumara, D. K. N. G., Wijesekara, A., \& D.G. Hunter., D. (2010). Kandyan home gardens: a promising land management system in Sri Lanka. Secretariat of the Convention on Biological Diversity, Colombo.

Rosenfeld, A. H., Akbari, H. Romm, J.J. \& Pomerantz, M. (1998). Cool communities: Strategies for heat island mitigation and smog reduction. Energy \& Buildings, 28 (1),51-62. https://doi.org/10.1016/S03787788(97)00063-7

Rudd, H., Vala, J., \& Schaefer., V. (2002). Importance of backyard habitat in a comprehensive biodiversity conservation strategy: A connectivity analysis of urban green spaces, Restoration Ecology, 10, 68375. https://doi.org/10.1046/j.1526-100X.2002.02041.x

Sanders, R.A. (1986). Urban vegetation impacts on the hydrology of Dayton, Ohio. Urban Ecology, 9 (3), 361 376. https://doi.org/10.1016/0304-4009(86)90009-4

Schipperijn, J., Bentsen, P., Troelsen, J., Toftager, M., \& Stigsdotter, U. K. (2013). Associations between physical activity and characteristics of urban green space. Urban Forestry \& Urban Greening, 12 (1), 109116. https://doi.org/10.1016/j.ufug.2012.12.002

Scott, K. I., McPherson, E. G., \& Simpson, J. R. (1998). Air pollutant uptake by Sacramento's urban forest. Journal of Arboriculture, 24 (4), 224-234.

SEDAC, (2007). Compendium of environmental sustainability indicators. The Socioeconomic Data and Applications Center (SEDAC), Columbia University, USA.

Shah, M.D., \& Haq, A. (2011). Urban Green Spaces and an Integrative Approach to Sustainable Environment. Journal of Environmental Protection, 2, 601-608. https://doi.org/10.4236/jep.2011.25069

Shanahan, D. F., Lin, B. B., Gaston, K. J., Bush, R., \& Fuller, R. A. (2014). Socio-economic inequalities in access to nature on public and private lands: A case study from Brisbane, Australia. Landscape and Urban Planning, 130, 14-23. http://dx.doi.org/10.1016/j.landurbplan.2014.06.005

Shanahan, D., Fuller, R. A., Bush, R., Lin, B. B., \& Gaston, K. J. (2015). The Health Benefits of Urban Nature: How Much Do We Need? BioScience, 65(5), 476-485. https://doi.org/10.1093/biosci/biv03

Shashua-Bar, L. \& Hoffman, M.E. (2000). Vegetation as a climatic component in the design of an urban street: an empirical model for predicting the cooling effect of urban green areas with trees. Energy and Buildings, 31 (3), 221-235. https://doi.org/10.1016/S0378-7788(99)00018-3

Shoup, L., \& Ewing, R. (2010). The economic benefits of open space, recreation facilities and walkable community design.A research synthesis. National Program of the Robert Wood Johnson Foundation, Princeton.

Sorensen, M., Smit, J., \& Barzetti, V., \& Williams, J. (1997) Good Practices for Urban Greening, InterAmerican Development Bank. Available at http://www.iadb.org/sds/doc/ENV109KKeipiE.pdf. [last accessed 1 July 2021]

Streiling, S. \& Matzarakis, A. (2003). Influence of single and small clusters of trees on the bio-climate of a city: A case study. Journal of Arboriculture, 29 (6),309-316.

Swanwick, C., Dunnett, N., \& Woolley, H. (2003). Nature, role, and value of greenspace in towns and cities: An overview. Built Environment, 29(2), 94-106. https://www.jstor.org/stable/23288809 
Tiwary, A., Sinnett, D., Peachey, C.J., Chalabi, Z., Vardoulakis, S., Fletcher, T., Leonardi, G., Grundy, C., Azapagic, A. \& Hutchings, T.R. (2009). An integrated tool to assess the role of new planting in PM10 capture and the human health benefits: a case study in London. Environmental Pollution, 157, 2645-2653. https://doi.org/10.1016/j.envpol.2009.05.005

Trinh, L. N., Watson, J. W., Hue, N. N., De, N. N., Minh N. V., Chu, P., Sthapit, B. R., \& Eyzaguirre. P. B. (2003) Agrobiodiversity conservation and development in Vietnamese home gardens, Agriculture Ecosystem Environment, 97, 317-344. https://doi.org/10.1016/S0167-8809(02)00228-1.

Ulrich, R. (1984). View through a window may influence recovery from surgery, Science, 224, 420421. https://doi.org/10.1126/science.6143402

United Nations Department of Economic and Social Affairs, (2015) World Urbanization Prospects: The 2014 Revision, United Nations

United Nations, (2014) Department of Economic and Social Affairs, United Nations.

Whitelaw, S., Swift, J., Goodwin, A. \& Clark, D. (2008). Physical activity and mental health: the role of physical activity in promoting mental well-being and preventing mental health problems. NHS Scotland, Edinburgh.

Wilbur, J., Chandler, P., Dancy, B., Choi, J., \& Plonczynski, D., (2002) Environmental, policy, and cultural factors related to physical activity in urban, African American women. Women's Health, 36,17-28, https://doi.org/10.1300/J013v36n02 03

Wolf, K.L. (2004). Trees and business district preferences: A case study of Athens, Georgia, US, Journal of Arboriculture, 30 (6), 336-346.

Wood, L., L. D. \& Frank, et al. (2010). Sense of community and its relationship with walking and neighborhood design. Social Science and Medicine, 70(9), 1381-1390, https://doi.org/10.1016/j.socscimed.2010.01.021

Xiao, Q., McPherson, E.G., Ustin, S.L., Grismer, M.E., \& Simpson, J. R. (2000). Winter rainfall interception by two mature open-grown trees in Davis, California. Hydrological Process, 14 (4),763-784. https://doi.org/10.1002/(SICI)1099-1085(200003)14:4<763::AID-HYP971>3.0.CO;2-7

Zhu, W. X. \& Carreiro, M. M. (2004). Variations of soluble organic nitrogen and microbial nitrogen in deciduous forest soils along an urban-rural gradient. Soil Biology and Biochemistry, 36 (2), 279-288. https://doi.org/10.1016/j.soilbio.2003.09.011 